Volume 4, No. 3, September - December 2019 ISSN: 2503-4235 (p); 2503-4243 (e)

Shirkah

Journal of Economics and Business 


\section{Shirkah}

Journal of Economics and Business

Vol. 4, No. 3, September-December 2019

ISSN: 2503-4235 (p); 2503-4243 (e)

\section{Editor in Chief}

Fitri Wulandari

\section{Managing Editor}

Jasanta Peranginangin

\section{Editorial Boards}

Abdul Azim Islahi

Islamic Economics Institute, King Abdulaziz University, Saudi Arabia

Abu Umar Faruq Ahmad,

UBD School of Business and Economics Universiti, Brunei Darussalam

Cedomir Nestorovic,

ESSEC Business School Asia Pacific, Singapore

Johan Fischer,

Department of Social Sciences and Business Roskilde Universitetscenter, Denmark Muhamed Zulkhibri,

Islamic Research and Training Institute, Islamic Development Bank, Saudi Arabia M. Kabir Hassan,

Department of Economics and Finance, University of New Orleans, United States Musa Asy'arie,

Faculty of Islamic Economics and Business, IAIN Surakarta, Indonesia

Nunung Nurul Hidayah,

Aston Business School, Aston University, Birmingham, United Kingdom

Saim Kayadibi,

Department of Economics, Kulliyyah of Economics and Management Science,

International Islamic University Malaysia, Malaysia

Shaikh M Ghazanfar,

Departement of Economics, University of Idaho, Russian Federation

Sigit $\mathrm{S}$. Wibowo, 
Department of Management, Faculty of Economics and Business, Universitas Indonesia, Indonesia

Vihang R. Errunza,

Desmarais Global Finance Research Centre, Desautels Faculty and Management, McGill University, Canada

\section{Assistant to Editor \\ M. Endy Saputro \\ M. Zainal Anwar}

Shirkah Journal of Economics and Business is a peer-reviewed journal published three times a year (January-April, May-August and September-December) by Faculty of Islamic Economics and Business, Institut Agama Islam Negeri (IAIN) Surakarta Central Java, Indonesia. The main objective of Shirkah is to offer an academic space of exchange ideas and initiate the increase number of qualified article produced by postgraduate students, practitioners and academicians.

\section{Editorial Office}

Ruang Jurnal Shirkah

Lantai Dasar, Sayap Barat, Fakultas Ekonomi dan Bisnis Islam, IAIN Surakarta

Jln. Pandawa No. 1, Kartasura, Sukoharjo, Jawa Tengah Kode Pos. 57168

Phone (+62271) 781516 Fax: (+62271)782336

E-mail: shirkahjournal@iainsurakarta.ac.id; shirkahiainsurakarta@gmail.com

Website: http://shirkah.or.id/ 


\section{Shirkah}

Journal of Economics and Business

Vol. 3, No. 3, September-December 2018

ISSN: 2503-4235 (p); 2503-4243 (e)

\section{Table of Contents}

\section{Articles}

M. Falikul Isbah

External Influences and Supports to Pesantren's Socio-Economic

Activism in Changing Context

R. Lukman Fauroni

The Economic Community of Pesantren Al-Ittifaq Opposing

Market Capitalism and the Improvement of Competitiveness

M. Musa Al Hasyim

403

Creative Industry Development in Pesantren Tebuireng

Kuat Ismanto

N. Nasrullah

429

Multiplier Effects of Pesantren Walindo

Mustaghfiroh Rahayu

455

Social Embeddedness and Economic Behaviour in Pesantren Mlangi

Helmi Haris

Muhammad Nashirudin

481

Lombok as an Indonesian Halal Travel Destination 


\title{
Social Embeddedness and Economic Behaviour in Pesantren Mlangi
}

\author{
Mustaghfiroh Rahayu \\ Department of Sociology, Faculty of Social and Political Sciences \\ Universitas Gadjah Mada \\ mth.rahayn@gmail.com
}

\begin{abstract}
In contrast to global research on the relationship between Islam and entrepreneurship, analyses which shows a negative trend, researches on this topic in Indonesia show different findings. Various researches show the positive impact of the teachings of Islam on Muslim entrepreneurial behaviour, including multiple studies conducted in Mlangi. Continuing the existing research, this research looks at the role of pesantren networks in entrepreneurial practices carried out by entrepreneurs as well as caregivers for pesantren in Mlangi. By using the social embeddedness theory, this research found out that there is a dialogue between rational choice, social context and pesantren networks in the business run by entrepreneurs cum caregivers of pesantren in Mlangi.
\end{abstract}

Keywords: social embededdness, Mlangi, pesantren entrepreneur

\section{Introduction}

Zelekha and colleagues in their study "Religious Institution and Entrepreneurship" stated that Islam is a religion that does not encourage entrepreneurship and economic development (Zelekha, 2014; Lewis, 2002). Zelekha's research uses data on entrepreneurial activity collected using a new approach from the online professional network, LinkedIn, in 176 countries. According to this research, Islam does not provide much individual freedom and gives limited ownership rights. One reason is that individuals are not so significant compared to the community. 
Besides that, the idea of fatalism is so powerful among Muslims. These factors make Muslims inclined not to encourage individual effort and also entrepreneurial competition.

However, empirical researches in Indonesia show different data. The studies of Irwan Abdullah in Jatinom and Radjasa Mu'tasim and Abdul Munir Mulkhan on the economic activities of the Syadzaliyah's Sufi order in Kudus emphasized that the santri was far more productive than the nationalists, or priyayi. Nationalists are more likely to choose a career as a civil servant (Abdullah, 1994; Mu'tasim and Mulkhan, 1998). This report will complement empirical data on Muslim economic activities that will contribute to the face of global Muslim entrepreneurs by taking a location in Mlangi Hamlet, Nogotirto Village, Gamping District, Sleman Regency, Yogyakarta Special Region.

The relation of religion and economic activities in Mlangi has been studied by several scholars. Destha T. Rahardja (2003), in his research on convection entrepreneurs in Mlangi, stated that Mlangi entrepreneurs run a rational strategy in managing their business (Rahardja 2003, 131). The form of the sensible approach is to hand over the work to other parties, such as workers, subcontracting work to other parties, and prioritizing the workmanship of the product being sold. Meanwhile, Supraja’s (2009) study of business and sufi order in Mlangi shows that the teachings of sufism help business people in Mlangi face the crisis and rise again. It became one of the factors how businesspeople in Mlangi were able to change their strategies and products to survive. In this study, Supraja also explained the contribution of the Tarekah Qodiriyah Naqsabandiyah network of practitioners in the business development of Mlangi entrepreneurs.

However, the two studies do not adequately explain the relationship between social interaction with rational choices that Mlangi entrepreneurs have. This research on social embeddedness will try to target that area so 
that it can reveal more clearly what are the contexts that encourage and hinder the business of entrepreneurs cum pesantren caregivers in Mlangi. Specifically, this research will look at the role played by pesantren social networks in the process of social embeddedness. The primary data was obtained from in-depth interviews with two main informants, namely Mba Davin (PP As-Salafiyah) and Mba Eyfa (PP Ar-Risalah). Meanwhile, I also conducted another interview to complete the data, especially the section on social change in Mlangi, namely Kyai Hasan Abdullah and Gus Barrun.

\section{The History of Mlangi}

Mlangi is a sub-village in the northwest of the city of Yogyakarta. It administratively located in the village of Nogotirto, Gamping District, Sleman Regency. However, Mlangi does not always refer to Mlangi in a geographical sense, but it also applies to the place where the descendants of Mbah Kyai Nur Iman, Mlangi's ancestors, lived. One can be called the people of Mlangi, not only because he lives in the Mlangi administrative area, but also for those who have a genealogical relationship with Mbah Kyai Nur Iman.

Kyai Nur Iman, according to the oral story in Mlangi, was a descendant of the royal during the Mataram Islamic period. His name when he was little is Raden Mas Sandiyo. R. M. Sandiyo is the eldest son of R.P. Suryo Putro (the eldest son of Susuhunan Pakubuwono I) who has three siblings namely Pakubuwono II, R.M. Sujono (Hamengkubuwono I) and R. M. Mas Said (Mangkunegoro II). In his youth, he studied Islam with a Kyai in Gedangan, Sidoarjo until he married and lived there. However, R. M. Sandiyo is a salik who likes to explore. He was not satisfied with just studying in one place. On the way back to the palace, he had stopped at several pesantren to learn from the kyai in the area he passed. Not long 
after he lived in the palace, he decided to leave the palace.

There are several versions on why R. M. Sandiyo left the palace. One story states that R. M. Sandiyo escaped from the palace during the civil war between Yogyakarta and Surakarta due to Dutch's move, which later gave birth to the Giyanti agreement. At that time, he went west accompanied by two of his close friend; Sanusi and Tanwisani. First, they have stayed at Demang Adiwongso's house in Gegulu, Kulon Progo, then settled in the village of Susukan (Sayegan), a village in the western part of Sleman. (Rahardja, 2003: 84)

In 1757 there was the inauguration of the Ngayogyakarta Hadiningrat Palace, and Pangeran Mangkubumi were appointed to be the first king to hold the title Sri Sultan Hamengkubuwono I. The event took place in the village of Ambar Ketawang, a village not far from Mlangi. After the ceremony, the Sultan remembered his task of finding his eldest brother. The search was carried out by disguised as kawulo (layperson), until R. M. Sandiyo was found. When successfully found, the Sultan persuaded R. M. Sandiyo to return to the palace and may choose to stay in Surakarta or Yogyakarta. Responding to this offer, R. M. Sandiyo decided to remain in Yogyakarta but not in the palace.

Because of this decision, Sultan Hamengkubuwono I allowed him to choose a land/area he wanted. The large of the land was as large as the sound of the drum still heard. Finally, he decided to stay in Mlangi to teach Islam (mulang in Javanese). Mlangi comes from the word "mulangi" which means teaching. Since then, Mlangi has become a centre of Islamic education in the western region of Yogyakarta. Mlangi has long been famous as a santri (a person who seek for knowledge) village. Many majlis taklim exist in this village. Currently, there are 16 pesantren in this hamlet, and dozens majlis taklim, both managed by mosques and musholla, as well as individually in the homes. This is where Mlangi is unique because 
Mlangi community has a very close relationship with the palace, but at the same time, it is a centre for the development and teaching of Islam.

\section{The Economic Life in Mlangi}

Mlangi, aside from being a santri's village, is also well-known as a merchant/entrepreneur village. The trading habits of the Mlangi people have been formed through a long history. Initially, several Mlangi people worked as labourers in various batik industries in Yogyakarta, such as Prawirotaman, Kauman, Sosrowijayan, Patangpuluhan, and some even worked in the Banyumas area. Batik had experienced a boom in the 1960s to the 1970s. At that time, income as a stamp worker was up-and-coming (Supraja, 2009: 52). Labour income in one day at that time could be used to finance the necessities of life for a week. Therefore, with this income, they can buy land and also build houses.

The high wage received by "stamp" labourer facilitated workers from Mlangi to be able to open their batik industry. They work earnestly while trying to find out the ins and outs of making batik. Those who have mastered knowledge on batik then open their businesses in Mlangi. From them, batik gradually became the business of most Mlangi people. Mlangi village was progressively known as a developer of the batik, weaving and convection industry that has continued to this day.

Mlangi entrepreneurs and traders are creative and innovative. When the business of batik tulis (hand-drawn batik) and stamped batik went to bankruptcy because of the massive printing batik, they quickly thought of other alternative production. A home-based business emerged. They created the batik jumputan (tie-dye batik). (Interview with Kyai Hasan Abdullah, 10 April 2019). When Dagadu (a Jogja t-shirt brand that is quite expensive) was well-known as a souvenir from Jogja, Mlangi entrepreneurs make copies of these products with lower quality and 
cheaper.

The tradition and experience teach them how to be resilient and high-adaptation merchants. Even though experiencing an unfavourable economic condition, they were still able to survive. The worst conditions can motivate product innovation. Batik production in Mlangi emerged and developed in the 1950s. This continued with the creation of ATBM weaving which produced striated fabrics, sanitary napkins, napkins, and so forth. When the ATBM trend diminished, printing batik appeared to replace its position (Supraja, 2009: 58). Today, businesses related to cloth are still the mainstay of the majority of the Mlangi community. Some sell convection, supply fabric for convection makers, veil production, various mukena (prayer robe) motifs, face-covering slayer, cloth colouring, jumputan (tie-dye) batik are some of the business of the Mlangi community. Most of these activities are home industry. Mlangi people spend more time doing their work at home. They cut material, ngelir (give colour to the material), sew or do other work at home.

Previously, this home industry developed very rapidly, and one reason was it is run in the santri village. From the beginning until around the 2000s, the pesantren in Mlangi was a salaf (traditional) pesantren. Santri who study at this pesantren did not go to formal schools. So they have free time during the day after morning class. This condition was captured by the convection entrepreneurs in Mlangi to meet the needs of their workers. Moreover, most of them do not get shipments from their homes to live in pesantren. Therefore, they must work for a living. They are the motors of the convection industry in Mlangi to succeed in dominating the Malioboro and Beringharjo markets.

The existence of the santri as convection workers has more value in the eyes of the entrepreneurs. Siti Umiyah, one of the most successful convection entrepreneurs in the 90s, said that what made her business 
grow fast was because her employees were santri. Even though they started their work in the afternoon, because in the morning, they had to recite the Qur'an, but their presence brought blessings to their business. Almost every day, the students of these workers while doing their work, such as sewing or cutting materials, accompanied by reciting the Qur'an, or memorizing the pesantren's class material. Such an atmosphere is very appealing and is believed by Siti Umiyah as one of the reasons her business is progressing.

Since the 2000s conditions have changed. Modernity forces pesantren and santri to adapt to the change. Ownership of a formal school diploma is a necessity for the future. There are not many more santri who only go to pesantren in Mlangi without formal schools. This development was followed by the establishment of formal schools run by pesantren in Mlangi. Thus, the abundance of workers as in the heyday of Mlangi as a confectionary hamlet gradually faded. Mlangi entrepreneurs are required to look for non-santri workers who are actually more difficult, more expensive and have no moral guarantees. This change took place at the same time as the dim glory of the Mlangi convection due to the onslaught of the Pekalongan convection

\section{The Story of Two Women of Pesantren}

Mlangi is a santri village, as well as a merchant village. The livelihoods of most Mlangi residents are traders and craftsmen. Likewise, the livelihoods of most pesantren caregivers in Mlangi are no exception. The following are the stories of two women pesantren caregivers in Mlangi.

\section{Davinatul Ulum}

Davinatul Ulum is called as Davin or Mbak Davin. This 46-year-old woman is a third-generation caregiver at As Salafiyah Mlangi. As Salafiyah 
Islamic Boarding School is the largest pesantren in Mlangi at present. This pesantren s led by KH Suja'i, a murshid of the Qadariyah Naqsabandiyah order which has thousands of followers. Mba Davin is the eldest child of Kyai Suja'i. Kyai Suja'i is now very old and not involved in the daily activities of the pesantren. The day-to-day business of the pesantren was left by the four sons and daughter, all of whom lived in Mlangi. Mba Davin as the oldest child is responsible for the PP As Salafiyah takhasus (special) complex with her husband, Kyai Hasan Abdullah. There are currently around 160 santri in this complex. While the overall PP As Salafiyah students scattered in four complexes totalling around 1000 students.

However, Mba Davin's daily activities not only take care of her complex. As a hafidzah (one who memorizes the Qur'an), she also teaches the Qur'an in other compounds that are looked after by his younger siblings. Usually, she meets the students of the takhasus complex in the morning after the morning prayer. After that, around $09.00-10.00$, she teaches students in the integrated complex, where students of MTs (junior high school) and MA (senior high school) live. There were around 40 - 50 santri who are memorizing the Qur'an and ask for mba Davin's guidance.

As Nyai, the wife of a kyai who is active in social activities, Mba Davin is very busy. In addition to her routine teaching, she also has to take care of guests who often come to her house. However, these various activities did not dampen his intention to do business. Mba Davin only started her business after she married Kyai Hasan in 1991. When she was married, Mba Davin was still a santri at PP Sunan Pandan Aran Yogyakarta, and Kyai Hasan was the trusted and senior santri of Kyai Suja'i who was asked to help to teach at the pesantren. After marriage, like most of Mlangi's children, they lived with their parents and for their daily needs were supported by their parents. Only when she was pregnant for her first child, her mother advised Mba Davin to start a business, because her husband's income was uncertain. With the help of her mother, she started 
a business. Her mother was her best mentor.

There is an interesting tradition in Mlangi regarding this business practice. In Mlangi there is a term "ngayuh" which means to borrow people's things to sell. Because the surrounding environment is a producer of various products, it is effortless for people to acquire goods from producers or big traders to sell. This is the way Mba Davin started her business. Initially, she only borrowed convection from the owner of an enterprise to sell. She took ten pieces and sold them to neighbours and acquaintances, if it were sold five pieces, the profits set aside to prepare for the birth of his child and the rest could later be returned to the skipper and take another new model. Over time some customers order a particular model with a rather large amount. From here, Ms. Davin's business flourished.

Mba Davin had only sold a veil/veil. But she quitted this business because more often losers. According to her, selling the hijab is risky because the veil model is changing rapidly. When the old stock hasn't finished yet, and new models are out, then the old stocks are difficult to sell. Finally, she gives away the old stocks to relatives or anyone. At present, she is well established in her convection business. Mba Davin sells everyday clothes, not the expensive one that is only worn at certain times. For her, selling clothes that are worn every day is more profitable, because the needs are steady. No need to wait for a particular moment; the consumer needs the goods she sells. Most products sold are mukena (prayer robe), various models of Indonesian pyjamas, abaya, skirts and several models of women's clothing. Most of the goods are taken from the skipper in Pekalongan, while the rest is produced by herself. Among her products are plain mukena, embroidery mukena and women's clothing.

Mba Davin has an excellent relationship with the skipper in Pekalongan. Nowadays, Mba Davin doesn't have to go anywhere to run his business. Every time he needs goods, call the boss in Pekalongan, and 
the goods will be sent shortly. Most of the items she buys are goods ordered by her customers. Usually, customers contact Mba. Davin with a list of items needed, then Mba. Davin calls the skipper to ask for the availability of the items requested, if available, the shipment of goods will be processed quickly. If the products are not available, the skipper in Pekalongan will find another skipper, or be asked to wait. When goods arrive at Mlangi, they are immediately processed to be sent to their customers. So, not much stock is available at Mba Davin's house, except for self-produced goods.

Mba Davin's customers are mostly within pesantren networks; her old friends from pesantren when she was studying at PP Al Lathifiyah Tambak Beras Jombang and PP Sunan Pandanaran Yogyakarta, santri and alumni of the As Salafiyah pesantren, and colleagues in pesantren's organization. In addition to that, are family and neighbours around Mlangi. Trust is the main foundation in her business. Mba Davin does not always require its customers to send money first before sending goods. For customers who are also her old friends when nyantri, Mba Davin gives leeway to pay later. As it just happened a few weeks ago, he was asked to send goods to his customers who live in Jambi in quite a large amount, but the payment was promised after the haflah akhirus sanah (the ceremony to end the learning year) pesantren.

When asked about the turnover in a month, she claimed not to know exactly because she did not keep records. To be sure, every Monday, he sends money to the boss at least Rp. 11,000,000. That's just gross income from one type of merchandise. Meanwhile, he has other merchandise besides Pekalongan the product from Pekalongan. Mba Davin claimed to enjoy her business today. He doesn't need to go anywhere, only with the mobile phone she can run a business worth hundreds of millions. 'no need to go anywhere" is an important factor because its presence in pesantren is very much needed. Mba Davin said that her husband often 
reminded her to be grateful for this achievement. Because without much effort, he can run a business that is very helpful to the needs of the family. Compared to other entrepreneurs/traders in Mlangi, she is fortunate. As a businesswoman, Mba Davin is not the type of many profit pursuers. For her, this business is sufficient for her needs. She has no aspirations/ development targets. Everything flows as has been outlined by God. His prayer at any time is "Allahumma cukup - May Allah suffices her needs" (interview with Davin, April 8, 2019).

\section{Siti Fadbilah}

Siti Fadhilah or commonly called Mba Eyfa, is the only daughter of K. H. Abdullah. Kyai Abdullah is the founder of PP Ar Risalah Mlangi. How business and pesantren are strongly connected in Mlangi is very visible from the history of the late Kyai Abdullah. Kyai Abdullah was not born into a family that manages pesantren. However, every child in Mlangi must attend boarding school at a young age, regardless of his family's socioeconomic background. Likewise, with young Abdullah. Since graduating from elementary school, he was sent to Lasem to study religion. Spending years there, he continued nyantri with KH. Chudlori in Tegalrejo, Magelang. After feeling that his religious knowledge was enough, he returned to Mlangi and started trading.

Young Abdullah is known to be very good at trading. He has access to fabric factories in the Yogyakarta and Central Java regions. From there, he sold the fabric to a convection manufacturer in Mlangi. In doing so, he became a fairly calculated trader in Mlangi. Amid his success in business, he decided to "retire early" and began teaching the Koran. Day by day, the students increase. Finally, PP Ar Risalah was established in 2001. At present, the pesantren Ar Risalah is managed by his son-in-law, KH Syukron Amin, Mba Eyfa's husband. Kyai Sukron and Mba Eyfa worked for hand 
in hand to take care of pesantren with around 80's santri. Kyai Sukron oversees the learning process to master on reading and understanding Islamic teaching from Arabic book, while Mba Eyfa oversees the teaching of the Qur'an. Armed with her knowledge gained from the Krapyak and Al Falahiyah Mlangi pesantren, as well as the khafidzoh diploma, she has enough authority to teach the Koran.

Mba Eyfa started her business at a very young age, 19 years. She began to the business by selling anything that could "dikayuh"- borrowing goods from entrepreneurs to sell. If it doesn't sell, the item will be returned. This business is quite auspicious because all the items she takes are always sold. Then she expanded his business by requesting some good from several locations, such as Solo and Jakarta. There are many items she sells, such as clothes and accessories. But selling these products are somewhat troublesome because first, the choices are too many, so sometimes it takes a long time for communication to serve one customer. Second, the model also changes quickly. If there are unsold items, while models are already outdated, this product will never sell. As a result, she will lose. But as the daughter of a wealthy merchant, Mba Eyfa wasn't too concerned about that.

Then, at the end of 2011, her father (Kyai Abdullah) took the initiative to introduce Mba Eyfa to his friend who owns a batik convection factory in Solo. Kyai Abdullah intends to pave the way for Mba Eyfa to conduct business cooperation. Mba Eyfa chose to start women's sarong business that is usually worn by female students of pesantren. The form of collaboration is that this factory produces sarong with unique designs from Mba Eyfa and only sells them to her. This business is going well today. Within a week, this factory in Solo will send orders for Mba Eyfa twice. Earlier, Mba Eyfa relied on the pesantren network for marketing. She often travels to Purworejo, Kendal, Kebumen, Solo and other cities to 
promote her products to friends and alumni of the Ar Risalah pesantren. Now, the network is gradually getting more extensive. What's App Group is one of the factors driving the progress of her business. Through WAG, she found new customers.

Currently, she runs her business from home online. If there is a new model, she takes the photo and uploads it to her twitter account, IG and also his WA status. From there, customers know if there are new products that can be ordered. Most of her customers are resellers who sell their products to the next consumers. So, when the goods arrive, and she uploads on her social media, the buyer asks Mba Eyfa to process the shipment, but the sender's name is the customer. At present, the products already go abroad, such as Malaysia, Brunei Darussalam and Pakistan. Most customers are satisfied with the quality of the sarong because it is made from excellent quality fabric, thicker and the motives are distinct. The people of Pakistan like Eyfa Sarong products because the colours are bright and colourful. Mba Eyfa deliberately chose bright colours because it depicts excitement. Besides, the sarong also has another characteristic that is patterned flower or polka-dot. But if there are requests for other motives, she will find a way to fulfil the request by asking merchandise from other traders in Mlangi or outside Mlangi.

This sarong business is running quite successfully. She can sell 500800 pieces of the sarong in a week. She believes, as long as the pesantren exists, the market will continue. Mba Eyfa likes her business much because it's not complicated. Regarding the design, she only needs to convey her ideas to the people in the factory; they will translate them into pictures. Order is also quite easy, call, items are made and delivered. Also, the process of conducting her business is very easy because she only sells one type of product at one price, but the motives vary. This greatly facilitates in her communication with customers. 
In general, to run her online business, Mba Eyfa enforces regulations not to send goods before payment is made. Although most of her customers are dzurriyah (family) pesantren, Mba Eyfa enforces this rule for security reason. If she agrees on someone asking goods to be sent before payment, that's an exceptional case. It only can be done by customers who are already very close, and the payment tempo is only a week from the delivery. This can only happen, for example, in responding to the request of the family of Lirboyo (one respected and well-known pesantren in Kediri, East Java) who she appreciates so much.

This sarong business is one of many businesses run by the PP Ar Risalah family. Outside of this sarong business, they have a rented house of 18 rooms. One house is rented out to a shipping company, and a convenience store with a turnover of more than Rp. 2,000,000 a day. However, Mba Eyfa enjoyed running this sarong business. For her, this business can be a means to keep in touch with her friends at the pesantren and also to maintain her pesantren's networking. Her collaboration with the factory remains smooth even though the leadership has now changed to the children. For Mba Eyfa's family, "nyambut gawe iku niate ben entuk berkah. Berkah ki bakale tekan kiamat, kanggo tinggalan anak putu ra bakal entek" (work is actually intended to get God's blessings. God's blessing is eternal, it can be used as an inheritance for children and grandchildren) (Interview with Siti Fadhilah, 11 April 2019).

\section{Social Embeddedness}

Classical and neo-classical economic thinkers assume that rationality is a determinant factor in influencing economic action, thus social relations have a small portion of economic action (under-socialized). While other thinkers say that economic behavior and institutions are limited by social relations as a determinant factor (over-socialized). 
Granovetter (1985) tries to bridge these two poles of thought by proposing social embeddedness in understanding economic actions. Economic actors are attached to concrete social relations.

Granovetter's opinion is the development of Karl Polanyi's idea that economy is a process inherent in economic and non-economic institutions. Granovetter further stated that embeddedness is an argument which says that the behavior and institutions analyzed are highly dependent on ongoing social relations, assuming that they are an independent entity is an acute misunderstanding (Granovetter, 1985: 482). The basis of his argument is based on three premises, namely, that economic activity is a specific social activity, second, that economic activity is socially located and attached, and thirdly, that economic institutions are social construction (Granovetter, 1985)

Social embeddedness is contained in the inter-personal relations of economic actors and social networks. This occurs because economic processes are structured in non-market relations such as family, kinship, community or bureaucracy. When social relations have not been built closely in the interaction of economic actors, then rational calculations can be the basis for consideration in economic action. As an analytical concept, embeddedness talks about the role and importance of social networks in economic activity (Uzzi, 1997; Jack and Anderson, 2002)

There are at least two social networks can be analysed from the two pengasuh (caretaker) cum entrepreneurs of pesantren in Mlangi that I studied. The first social network is a social network as the residents of Mlangi who has a tradition of entrepreneurship from long time agi and has a very strong kinship ties, and the second is the pesantren social network that is gained due to the nyantri process and when becoming a pesantren caregiver. Network analysis requires the exchange of modes and content between people, where symbols (concepts, values and 
norms), emotions (love, respect and animosity), or goods and services are exchanged (Bogenhold, 2013). Viewing the economy as a box of tools (Schumpeter, 1954) enables one to identify social network analysis as an economic technique that allows to map economic behaviour, institution, and economic and social change.

Network analysis emphasizes the process. It informs personal experiences and beliefs that play an important role in economic activities. In the case of the two informants, which social network is more important is not easy to identify. If it is said that the pesantren social network has a more important role, this will undermine the role of the work ethic of the Mlangi community which they have internalized for generations. The work ethic of Mlangi residents is very typical. As a santri community, this very profane problem also becomes religious. For the people of Mlangi, work is not just for geting wealth, but it is a means to continue to worship God. If they have enough clothing, food and shelter, they will worship peacefully. Work for them is not just to meet the needs. That's why, Mlangi people never have a target in doing their business. That is considered by outsiders to be a lazy trait because they don't work hard every day. If they have enough money to live today, there's no need to think about tomorrow's needs. According to Gus Barrun, this is a translation of their tawakkal (surrender) to God (interview with Gus Barrun, 18 April 2019).

However, this relaxed ethos if needed can produce unexpected creativity. When batik printing slumped, suddenly Mlangi entrepreneurs gave birth to new creativity, namely making tie-dye batik which immediately dominated the Maliboro, Prambanan, and Borobudur markets. Some of them started the business of old cloth (mostly batik). This combination of surrender in economic endeavors and unexpected creativity is the uniqueness of the work ethic of the Mlangi community (interview with Kyai Hasan, 10 April 2019). This unique Mlangi community work ethic 
underpins the economic behavior of two informants in this study. For Eyfa, continuing the sarong business was a way for her to connect with friends in pesantren, the daughters of pesantren's owners, as well as PP Ar Risalah alumni who conduct similar business. As for Mba Davin, resignation towards God becomes a shield that protects her in running a business. She did not expect grandiose, she just hoped to get enough for her living with the expression "Allabumma cukup" (may God grants her enough living). Both of them do not have targets in running their business. They are quite happy and comfortable with the current achievements and do not think about making their business big and bigger.

Such a situation, for economic analysts might be regarded as irrational (Granovetter, 1985: 506). However, if we use social embeddedness analysis to see the economic behavior of the two pesantren caregivers, it might come to different conclusions. How can a business not have a target? It could be a rational choice for a society with a high level of religiosity. For them, Allah has guaranteed everyone's fortune. No need to rush to chase wealth. Work is necessary, but at night is a space for worship. There must be no economic activity at night. In addition, their position as pesantren caregivers who are very busy with their regular activities make them feel grateful for the current achievements. This was more than what they had imagined, so there was no need to over-expect by implementing the target.

Social embeddedness presupposes that economic activities are not solitary activities that are deprived of the social context. There is always a process of "dialogue" between rationality and social networks owned by economic actors. Understanding economic activity as a process of "dialogue" is not an easy problem especially because of the debate over two socialized and under-socialized poles. To make it easier, social embeddedness in the economic field can be seen in three arenas, namely "structural context", "processes" and "performance implication". (McKeever, Jack and Anderson, 2014: 226) 


\section{Structural Context}

Johannisson et al (2002) argue that entrepreneurs and their companies (production houses) are basically anchored in a larger structure, and within this structure, the economy and the social environment are generally not separate, and there are many sources of motivation and opportunities to carry out various realities (Johannisson and Monsted, 1997; Kloosterman, 2010). From here, economic activities are depicted as very complex and competing activities. To capture this dynamic, Uzzi (1997) suggests that we leave embeddedness analysis as a representation of the social complexity faced by entrepreneurs, but focus more on the development, use and the work of these relationships in a broader operational context (Johannisson and Landstorm, 1997; Uzzi, 1999).

Meanwhile, Jack and Anderson (2002) say when analyzing entrepreneurs (agents), context (structure) must be involved, because the whole social context is more important than individual parts. Therefore, how these entrepreneurs are socially attached and how they are attached (their suitability to the structure) will affect their ability to read social and economic resources (Portes and Sensenbrenner, 1993). Mlangi's structure, which is largely entrepreneurial, provides a context for Mba Eyfa to have the courage to start a business at a relatively young age while there was no urgent need to do so. The experience of the people around him who are good at running a business makes Mba Eyfa dare to try to do business. She started her business by trial and error. Where there are goods needed by consumers, she will sell. Such mentality is the result of a social structure that has a high entrepreneurial spirit.

So does Mba Davin, the economic structure in Mlangi benefits her in doing business. The large number of entrepreneurs in Mlangi can be interpreted as a broad learning space where she can ask anything related to business. Her mother, a reliable businessman, became a place to learn 
in the early days of running a business. Mlangi's social structure as a santri village and has special relationship with the palace, gives more value to Mlangi entrepreneurs who do business on pesantren's product to be trusted by prospective buyers. Mlangi's big name can be the basis of legitimacy when they offer their merchandise to pesantren.

\section{Processes}

Another arena for seeing social embeddedness is in the process of how business practices are embedded in social relations and changing the logic of how business is run (Jack and Anderson 2002). Attention to this process changes the expectations associated with transactions to get maximum results towards a more social outlook. According to Jack and Anderson (2002), the attachment process consists of: 1. "Understanding" the nature of structure; 2. "Establish" the structure, and 3. "Maintain" links and structure.

In this case, the community and social structures provide the context, location and mechanism to become attached. Therefore, the embedding process is about establishing and maintaining social relations that allow an entrepreneur to become an integral and maintain structural integrity. Littunen (2000) sees this embedding process as a time when employers operationalize the context and special habits of private entrepreneurs that are considered reasonable for the perpetrators, and generally cannot be reasoned to outsiders.

Mlangi's very religious social structure provides a context for entrepreneurs to internalize Islamic values in their economic behavior. The view that work is to seek blessings, not just money, work to establish friendship, the belief that God is very fair in dividing fortune, and help people who are unable as a positive practice, make the business orientation of these entrepreneurs somewhat different from most entrepreneurs outside 
Mlangi. By looking at their religious context and their outlook on life, it becomes quite easy to understand why they don't have targets in their business. Not only never make target in business, most Mlangi people also do not make targets related to their lives. They are not worried about the question of when to have a house, when to buy a car and other life targets. Life is set up, their job is only to try and surrender to God (tawakkal), according to the majority view of the Mlangi community, including two entrepreneurs in this study.

Besides that, the very close kinship relations make Mlangi people have quite high trust towards fellow citizens. Starting a business with "ngayuh" will not happen if there is no trust as the foundation. The fact that all Mlangi residents are basically brothers and sisters makes the practice of ngayuh possible. Once again, a process like this is considered natural for Mlangi people, but rather different for people outside Mlangi.

\section{Performance Implication}

Social embeddedness is recognized as relevant to entrepreneurial activities because it is a mechanism that helps entrepreneurs identify resources through socialized media (Hansen 1995; Hite 2005). In a simple way, Uzzi (1997) described this as an opportunity to clearly explain "how" and "why" social ties influence entrepreneurial outcomes. The way it works is by understanding the social context in which employers are attached, influencing performance by providing a moral framework that determines what type of behavior is socially appropriate. However, embeddedness can also act as a barrier to performance. Uzzi identifies several conditions when embeddedness becomes an obstacle, for example the unexpected exit of the core network, the power of institutions to rationalize markets, etc.) (Uzzi, 1997: 17). 
The way of life of the Mlangi people who highly respected the kyai (the head of a pesantren) and the habaib (a plular version of habib, a descendant of the Prophet, Muhammad SAW) was once a hindrance in the performance of Mba Davin. When a Syarifah (the female descendant of the Prophet) who lives outside of Yogyakarta asks for an item to be sold, without objection she fulfills it. For her, syarifah just as habaib is has a moral guarantee and it is implemented in business practice. So when the goods brought after long time no news, at first she did not believe that a sarifah can do that. However, when contacted many times and never received a positive response, even finally could not be contacted at all, she believes that the syarifah can have bad character. This experience opened her eyes and shook the structure of her knowledge of syarifah.

However, not all pesantren caregivers cum entrepreneurs take advantage of the pesantren network in running their business. Gus Barrun is one of them. Gus Barrun is one of the heirs of the authentic Mlangi tradition. Since his boarding school he has been thinking about what form of entrepreneurship will be carried out when he returns to Mlangi. After marriage, he immediately started a business of selling cloth. Gus Barrun took the goods from the factory directly. Sometimes from factories in Solo, Jogja and even Pekalongan.

He is aware that the best business done in Mlangi is a convection business. However, this business requires a complicated work from manufacturing to marketing. According to him, if he participated in running this business, the time to teach in pesantren would be reduced. Therefore, he chose a fabric business that was quite simple. Especially now, he was helped with technology. Almost everyday he was only at home teaching the Koran and also taking care of the pesantren. The business is run through mobile phones. If there is an order, he only needs to contact the factory, the factory will send to the customer through the expedition service. Goods do not need to be brought to Mlangi. 
Among his customers, no one has a relationship with the pesantren. One customer from Madura, for example, he found when there was an exhibition at JEC (Jogja Expo Center). At that time, the fabric-picking entrepreneur was exhibiting at JEC, Gus Barrun came to offer his products to the entrepreneurs. It turned out that there was a positive response from this businessman and he is now his customer. In one month the fabric turnover sent to Madura reaches 1 billion. The other customer he is looking for is through market readings. When sarongs from Tuban flooded into Yogyakarta, he went to Tuban to offer cloth material for sarong. As a result, the business relationships that have existed have survived to this day.

Gus Barrun's business practices are the exceptions of the two business practices of pesantren businessman cum caregivers that I described and analyzed above. One reason is the product that he sells. Fabric buyers are usually big businessmen. While the pesantren network which he owns has more to do business in a small scale and oriented to finished goods, such as clothes, negligee, robe or sarong. However, although the pesantren social network is not a major factor in its business practices, Mlangi's social network with an entrepreneurial ethos strongly influences his business choices and methods. The choice of fabric business is very much influenced by the tradition of fabric-based entrepreneurship in Mlangi. Meanwhile, religious factors also greatly influence the choice of business forms. According to Gus Barrun, al Ghazali once said that the best business was buying and selling cloth, "that's the trading of heaven" (interview with Gus Barrun, 18 April 2019).

\section{Conclusion}

So far research on embeddedness has seen this theme in the realm of families (Aldrich and Cliff 2003), ethnicity (Ram et al, 2002), social class (Anderson and Miller 2003) and gender (Louch). The general 
message of much of this research is that embeddedness in social networks and different contexts gives access to different resources and possibilities. In this research I use the realm of religious communities, namely the santri village, as a context in seeing embeddedness. Similar to the conclusions of the previous study, the context of the santri village and the pesantren social network provided information on different resources and practices. The strong view of religion as a foundation in conducting business, produces an economic practice that does not make financial profit as the main goal. The closeness of kinship in the village of Mlangi shows that economic practice does not always have to start with financial capital, but can be done only with trust capital. Finally, this study will complement the realm of context in research on embeddedness by revealing the realm of religion and pesantren in Indonesia. 


\section{References}

Abdullah, Irwan. (1994). The Muslim Businessman of Jatinom. Amsterdam: Universiteit van Amsterdam

Aldrich, H.E. and Cliff, J.E. (2003). 'The Pervasive Effects of Family on Entrepreneurship; toward a Family Embeddedness Perspective', Journal of Business Venturing, 18(5), 573-96

Anderson, R. and Miller, C. (2003). 'Class Matters: Human and Social Capital in the Entreprenural Process', Journal of Socio-Economics, 3291), $17-26$

Bogenhold, Dieter. (2013). 'Social Network Analysis and the Sociology of Economics: Filling a Blind Spot with the idea of social embeddedness', The American Journal of Economics and Sociology, Vol. 72, No. 2 (April)

Granovetter, Mark. (1985). "Economic Action and Social Structure: The Problem of Embeddedness", American Journal of Sociology, Vol. 91, No. 3 (Nov)

Hensen, E.L. (1995). 'Entrepreneurial network and new organization growth', Entrepreneurship: Theory and Practice, 19(4), 7-19

Hite, J. M. (2005). 'Evolutionary Processes and Paths or Relationally Embedded Network Ties in Emerging Entrepreneurial Firms', Entrepreneurship: Theory and Practice, 29(1), 113-44

Jack, S.L. and Anderson, S.L. (2002). 'The Effect of Embeddedness on the Entrepreneurial Process', Journal of Business Venturing 17(5), 476-87

Johannisson, B. and Landstrom, H., (1997). 'Research in Entrepreneurship and Small Business: State of the Art in Sweden', in H. Landstrom, H. Frank, J.M. Veciana, (eds), Entrepreneurship and Small Business Researchin Europe, An ECSB survey, Aldershot, UK: Avebury

Johannisson, B. and Monsted, M. (1997). 'Contextualizing Entrepreneurial Networking', International Studi of Management Organisation, 27(3), 109-36 
Johannisson, B., Ramiirez-Pasilas and Karlsson, G. (2002). 'The Institutional Embeddedness of Local Inter-firm Networks: A Laverage for Business Creation', Enrepreneurship and Regional Development, 14, 297-315

Kloosterman, R. (2010). 'Matching Opportunities with Resources: A framework for Analyzing (Migrant) Entrepreneurship from a Mixed Embeddedness Perspective', Entrepreneurship and Regional Development, 22(1), 25-45

Littinen, H. (2000). 'Networks and Local Environmental Characteristics in the Survival of New Firms', Small Business Economic, 15(1), 59-71

McKeever, Edwar., Anderson, Alastair., and Jack, Sarah. (2014). "Social Embeddedness in Entrepreneurship Research: the Importance of context and community" in Chell, Elizabeth dan Karatas-Ozkan, Mine (ed), "Handbook of Research on Small Business and Entrepreneurship, London: Edward Elgar, Vol. 11

Mu'tasim, Radjasa and Mulkahn, Abdul Munir. (1998). Bisnis Kaum Sufi, Yogyakarta: Pustaka Pelajar

Portes, A. and Sensenbrenner, J. (1993). 'Embeddedness and Immigration: Notes on the Social Determinants of Economic Action', American Journal of Sociology, 98(6), 1320-50

Rahardja, Destha T. (2003). "Ekonomi Moral dan Rasional Pengusaha Konfeksi di Mlangi”, in Ahimsa-Putra, Heddy Shri, Ekonomi Moral, Rasional dan Politik, Yogyakarta: Kepel Press

Ram, M., Smallbone, D. and Deakins, D. (2002). Access to Finance and Business Support by Ethnic Minority Firms in the UK, London, British Banker Association

Schumpeter, J. A. (1954). History of Economic Development. New York and Oxford: Oxford University Press

Supraja, M. (2009). Bisnis dan Tarekat: Studi tentang kegiatan bisnis komunitas tarekat Qodiriyah Naqsabandiyah, Mlangi, Yogyakarta, Yogyakarta: Media Wacana, 
Uzzi, B. (1997). 'Social Structure and Competition: the Paradox of Embeddedness', Administrative Science Quarterly, 42, 35-67

Uzzi, B. (1999). 'Embeddedness and the Making of Financial Capital: How social Relations and Networks Benefit Firms Seeking Finance', Amerincan Sociological Review, 64(4), 481-505

Zelekha, Yaron, Avnimelech, Gil, Sharabi, Eyal. (2014). "Religious Institution and Entrepreneurship", Small Business Economic, Vol. 42, No. 4, Special Issue: Small Business, Innovation, and Entrepreneurship 


\section{Shirkah Author Guidelines}

Shirkah currently offers two routes to submit manuscripts. We highly recommend to submit the articles which are made using OJS (Open Journal System). Feel free register as author soon through visiting http:// shirkah.or.id/index.php/home/user/register. The authors may directly send their manuscripts, along with their resume, to shirkahiainsurakarta@ gmail.com. Please prepare your manuscripts, using following guidelines:

1. Manuscript must be written in English. Submitted articles should not have been published or be under review for publication with another journal.

2. Manuscript's length is about $15-20$ pages, typed in one-half spaced on A4-paper size.

3. Manuscript must include an $150-200$ word abstract and keywords.

4. Manuscript must be arranged as follows: Title, Name of Author, E-mail address, Abstract, Keywords, Introduction (including method if any), Discussion, Conclusion, References.

5. Manuscript's titles not more than ten words.

6. Manuscript must be submitted in Microsoft Word or RTF.

7. Arabic words should be transliterated according to the style of International Journal of Middle Eastern Studies.

8. Manuscript references are preferably derived from the up-to-date references.

9. The author's resume should be submitted separately, consisting of at least full name, institutional address, phone number, areas of studies, and recent publications (if any).

10. Shirkab use APA Style 6th edition (2010) as reference format writing. We suggest the use of a reference manager software such as Mendeley, Zotero, and Endnote at templating the citation style. APA Style to be used is as follows: 


\section{Book with single author}

Swann, G. M. Peter. (2014). The Economics of Innovation an Introduction. Cheltenhum \& Northampton: Edward Elgar.

in-text citation: (Swann, 2014)

\section{Articles in reference books}

Alatas, S. F. (2006). Islam and the Science of Economics in Abu Rabi', I.M. The Blackwell Companion to Contemporary Islamic Thought. USA: Willey-Blackwell (pp. 587-606).

in text citation: (Alatas, 2006)

\section{E-Book}

Hackett, Rosalind (2007). "Religous Dimentions of War and Peace: Introduction.” Dalam Gerrie ter Haar dan Yoshio Tsuruoka (Ed.), Religion and Society: An Agenda for the 21st Century (h. 3-6). Retrieved from http:// brill.nl.

in text citation: (Hackett, 2006)

\section{Master's thesis, from a commercial database}

McNieI, D. S. (2006). Meaning through narrative: A personal narrative discussing growing up with an alcoholic mother (Master's thesis). Available from ProQuest Dissertations and Theses database. (UMI No. 1434728)

in text citation: (Mc Niel, 2006)

\section{Doctoral dissertation, from an institutional database}

Adams, R. J. (1973). Building a foundation for evaluation of instruction in higher education and continuing education (Doctoral dissertation). Retrieved from http://www.ohiolink.edu/etd/

in text citation: (Adams, 1973) 


\section{Doctoral dissertation, from the web}

Bruckman, A. (1997). MOOSE Crossing: Construction, community, and learning in a networked virtual world for kids (Doctoral dissertation, Massachusetts Institute of Technology). Retrieved from http:/www-static. cc.gatech.edu/--asb/thesis/

in text citation: (Bruckman, 1997)

\section{Journal article with No DOI}

Bourkhis, K., and Nabi, M. S. (2013). Islamic and conventional banks' soundness during the 2007-2008 financial crisis. Journal Metrics, 22(2), 68-77.

in-text citation: (Bourkhis \& Nabi, 2013).

\section{Journal article with DOI}

Ichwan, M. (2012). The Local Politics Of Orthodoxy: The Majelis Ulama Indonesia in the Post-New Order Banten. Journal Of Indonesian Islam, 6(1), 166-194. doi:http://dx.doi.org/10.15642/JIIS.2012.6.1.166-194

In text citation : (Ichwan, 2012)

\section{Abstract as citation}

Hasan, N. (2012). Islamist Party, Electoral Politics And Da'wah Mobilization Among Youth : The Prosperous Justice Party (PKS) in Indonesia. Journal of Indonesian Islam, 6(1), 17-47. Abstract from http:// jiis.uinsby.ac.id/index.php/jiis/article/view/97

in text citation : (Hasan, 2012)

\section{Mass media article}

Sahal, Akhmad (2014, March 2). Kiai Sahal dan Realisme Fikih.Tempo Magazine, p. 120.

in text citation : (Sahal, 2014) 


\section{Research report}

Fisher, B. S., Cullen, F. T., \& Turner, M. G. (2000). The Sexual Victimization of College Women. Research Report.

in text citation : (Fisher, Cullen, Turner, 2000)

\section{Monograph}

Routray, Bibhu Prasad (2013), National Security Decision-Making in India (RSIS Monograph No. 27). Singapura: Rajaratnam School of International Studies.

in text citation : (Routray, 2013)

\section{Proceeding article}

Sudibyakto, Hizbaron, D.R., \& Jati, R (Ed.) (2009), Proceeding International Seminar Disaster Theory, Research and Policy. International seminar held by Sekolah Pascasarjana, Universitas Gajahmada, Yogyakarta, 8-9 Desember 2009.

in text citation : (sudibyakto and Jati, 2009)

\section{Paper conference/seminar/symposium}

Janutama, Herman Sinung (2011). "Kraton dan Hubungan Antar Agama." Paper presented in Seminar Kraton dan Panatagama held by Center for the Study of Islam and Social Transformation (CISForm), Yogyakarta, 17 November.

$$
\text { in text citation :(Janutama, 2011) }
$$

\section{Online article in web}

Shiva, (2006, February). Bioethics: A Third World Issue. Native-web. Diperoleh dari http://www.nativeweb.org/ pages/legal/shiva.html 


\section{in text citation : (Shiva, 2006)}

\section{Online research report}

Kessy, S. S. A., \& Urio, F M. (2006). The contribution of microfinance institutions to poverty reduction in Tanzania (Research Report No. 06.3). Retrieved from Research on Poverty Alleviation website: http://www. repoa.or.tz /documents_storage/Publications/Reports/06.3_Kessy_and_ Urio.pcif

in text citation : (kessy and urion, 2006)

\section{Holy book}

Qur an, $2(25)$

In text citation : (Q. al-Baqarah 2:25).

\section{Encyclopaedia}

Graycar, Adam (1992). Social Welfare Policy. Dalam Mary Hawkesworth dan Maurice Kogan (Ed.), Encyclopedia of Government and Politics (Vol. 1). London: Routledge.

in text citation : (Graycar, 1992)

\section{Interview}

Sultan Hamengkubuwono X (interview, 2011, April 19)

in text citation : (Hamengkubuwono, 2011)

\section{Documentary film}

Steijlen, Fridus (2008). A Day in the Life of Indonesia [documentary film, 58 minutes]. Leiden: KITLV Press.

in text citation : (Steijlen, 2008) 
Vol. 4 No. 3, September - December 2019 